\title{
Prevalence of Thyroid Dysfunction and its Relationship with Severity of Depression among Patients of Depression Attending Tertiary Hospital
}

\author{
Arati Thapa, ${ }^{1}$ Mukesh Karki, ${ }^{2}$ Aradhana Thapa ${ }^{3}$ \\ ${ }^{1}$ Department of Psychiatry, College of Medical Sciences, Bharatpur, Chitwan, Nepal, ${ }^{2}$ Department of Surgery, College \\ of Medical Sciences, Bharatpur, Chitwan, Nepal, ${ }^{3} \mathrm{MPH}$, Kathmandu, Nepal.
}

\begin{abstract}
Background: Thyroid dysfunction is common feature among patients presenting with depression. The aim of this study was to estimate the prevalence of thyroid dysfunction in patients with depression attending Psychiatry outpatient department of College of Medical Sciences and Teaching Hospital, Chitwan, Nepal and to investigate its relationship with the severity of depression.
\end{abstract}

Methods: A total of 259 who attended the Psychiatry OPD of College of Medical Sciences and Teaching Hospital were enrolled over a period of 6 months after taking informed written consent. These patients were diagnosed as depression as per the ICD-10/ DCR criteria. The severity of illness was determined by using HAM-D. Thyroid profiling was done against common thyroid hormones TSH, FT3 and FT4 by standard method. Data was analyzed using SPSS.

Results: Among 259 patients, thirty patients (18.40\%) were found to have thyroid dysfunction, sub-clinical hypothyroidism was seen in $23(14.1 \%)$ followed by $3.1 \%$ with overt hypothyroidism and $1.2 \%$ with overt hyperthyroidism. However, there was no significant association found between severity of depression and thyroid dysfunction.

Conclusions: This study concluded that there was high prevalence of thyroid dysfunction in patients with major depression. Thus screening of thyroid test among depressive patients may be helpful in proper management of cases.

Keywords: prevalence; depression; HDRS; ICD-10 DCR Criteria; thyroid dysfunction.

\section{INTRODUCTION}

Depression is a common illness worldwide, with more than 300 million people affected. ${ }^{1}$ The WHO has ranked depression the $4^{\text {th }}$ leading cause of disability worldwide and projects that by 2020 , it will be the second leading cause. ${ }^{2}$ The average life time prevalence of major depressive disorder is $12 \%{ }^{3}$ It is estimated that 10 to $25 \%$ of women and 5 to $12 \%$ of men suffer from a major depression during their lifetimes. ${ }^{3}$ Studies have shown association between thyroid function disorder and depression. Similarity of symptoms in severely depressed and hypothyroid patients, the therapeutic use of thyroid hormones in the management of depression and the apparent abnormalities in the hypothalamic-pituitary-thyroid axis of subjects with depression has led to an observation of the association. ${ }^{4}$

Primary thyroid disorders including both hypothyroidism and hyperthyroidism may be accompanied by various neuropsychiatric manifestations ranging from mild depression and anxiety to overt psychosis. Dysphoria, anxiety, irritability, emotional lability and impairment in concentration constitute the classical neuropsychiatric symptoms occurring in hyperthyroidism or thyrotoxicosis. ${ }^{5}$ On the other hand, hypothyroid patients frequently demonstrate features of depression, cognitive dysfunction, apathy, and psychomotor slowing. In severe forms of hypothyroidism, clinical symptoms may mimic that of melancholic depression and dementia. ${ }^{6}$ When thyroid abnormalities exist, they consist mainly of elevated T4 levels, low T3, elevated rT3, blunted TSH response to TRH, positive antithyroid antibodies and elevated cerebrospinal fluid (CSF) TRH concentrations. This could result from a defect in the thyroid hormone receptor, ${ }^{7}$ or in the thyroid hormone transport and uptake into the brain and neuronal cells. ${ }^{8,9}$ The prevalence of depressive symptoms in hypothyroidism is near to $50 \%$ whereas in hyperthyroidism it reaches up to $28 \%$ of the cases. ${ }^{10}$ In psychiatric populations, the rate of clinical hypothyroidism ranges from 0.5 to

Correspondence: Dr. Arati Thapa, Department of Psychiatry, College of Medical Sciences, Bharatpur, Chitwan, Nepal. Email: th.aarti@gmail.com. Phone: +977-9819014425. Article received: 2020-03-27. Article accepted: 2020-09-12. 
$8 \% .{ }^{11}$ There are few studies which have examined the prevalence of thyroid dysfunction in major depressive patients in Nepal. Ojha et al, performed a cross-sectional study to examine the prevalence of thyroid dysfunction in depressive patients had found that $21 \%$ of depressive patients had abnormal thyroid function tests, $11.8 \%$ had subclinical hypothyroidism, $\quad 5.7 \%$ had subclinical hyperthyroidism, and the remaining $4.3 \%$ had overt hypothyroidism. ${ }^{12}$ Study conducted in Nepal showed that $42.8 \%$ of depressive patients were having some form of thyroid dysfunction with 28.5 $\%$ having subclinical hypothyroidism. ${ }^{13}$ This research aims to examine the prevalence of thyroid dysfunction in patients with major depressive disorder and to explore if there is any relationship between the two.

\section{METHODS}

This study is a hospital based-cross sectional descriptive study conducted in College of Medical Sciences and Teaching Hospital, in Chitwan district of Nepal, over a period of 6 months from July 2019 to December 2019. All patients with unipolar depression from outpatient department fulfilling the inclusion criteria were enrolled after informed written consent. A total of 259 unipolar depression patients were included. Ethical clearance was obtained from the ethical committee of the institutional review board of COMSTH. Patients of the age group 18-65 years, irrespective of their genders, diagnosed of unipolar depression as per ICD 10/DCR criteria, were included. While, patients with co morbid medical illness or any other psychiatric disorder were excluded.

\section{Tools}

A semi structured proforma was used for the assessment of the socio-demographic and clinical variables of the patients. Diagnosis of depression was made using ICD-10/DCR criteria. Hamilton Rating Scale for Depression (HAM-D) was used for comparison with the clinical diagnosis of depression. Thyroid function tests were ordered in the lab and were evaluated. The normal value of free T3 range between $1.21-4.18 \mathrm{pg} / \mathrm{ml}$, free T4 range between $8.9-17.2 \mathrm{pg} / \mathrm{ml}$ and of TSH range between $0.3-4.5$ microunits $/ \mathrm{ml}$ was taken in the COMSTH Biochemistry laboratory. Thyroid function test panel were assayed by the Chemiluminescent Immuno Assay technique using standard kit.

\section{Definition of thyroid status}

Euthyroidism was defined as normal freeT3, freeT4 and TSH. Abnormal thyroid status was

\begin{tabular}{|c|c|c|c|c|}
\hline \multicolumn{2}{|c|}{ Variable } & Normal thyroid status $(\mathrm{n}=185)$ & Abnormal thyroid status $(n=74)$ & $P$ value \\
\hline \multicolumn{2}{|c|}{ Mean Age $\pm S D$ in years } & $35.41 \pm 14.50$ & $35.29 \pm 14.48$ & 0.955 \\
\hline \multirow{3}{*}{ Sex } & Male & $69(26.64 \%)$ & $15(5.79 \%)$ & 0.008 \\
\hline & Female & $116(44.78 \%)$ & $59(22.79 \%)$ & \\
\hline & Married & $132(50.96)$ & $55(21.23 \%)$ & 0.531 \\
\hline \multirow[t]{4}{*}{ Marital status } & Unmarried & $51(19.69 \%)$ & $19(7.33 \%)$ & \\
\hline & Separated & $2(0.77 \%)$ & $0(0 \%)$ & \\
\hline & Illiterate & $59(23.31 \%)$ & $34(13.12 \%)$ & 0.077 \\
\hline & Primary & $11(4.24 \%)$ & $0(0 \%)$ & \\
\hline \multirow{5}{*}{ Education } & Secondary & $43(16.60 \%)$ & $20(7.72 \%)$ & \\
\hline & SLC & $6(2.31 \%)$ & $0(0 \%)$ & \\
\hline & Intermediate & $42(16.21 \%)$ & $12(4.63 \%)$ & \\
\hline & Graduate & $23(8.88 \%)$ & $1(3.08 \%)$ & \\
\hline & Upper & $15(5.79 \%)$ & $0(0 \%)$ & \\
\hline \multirow[t]{5}{*}{ Socioeconomic status } & Middle & $136(52.50 \%)$ & $53(20.46 \%)$ & 0.008 \\
\hline & Lower & $34(13.12 \%)$ & $5(3.06 \%)$ & \\
\hline & Unemployed & $5(1.93 \%)$ & $3(1.15 \%)$ & 0.011 \\
\hline & Housewife & $78(30.11 \%)$ & $44(16.98 \%)$ & \\
\hline & Business & $25(9.65 \%)$ & $3(1.15 \%)$ & \\
\hline \multirow{5}{*}{ Occupation } & Farmer & $18(6.94 \%)$ & $5(1.93 \%)$ & \\
\hline & Laborer & $12(4.63 \%)$ & $5(1.93 \%)$ & \\
\hline & Service & $23(8.88 \%)$ & $3(1.15 \%)$ & \\
\hline & Student & $22(8.49 \%)$ & $11(4.24 \%)$ & \\
\hline & Others & $2(0.77 \%)$ & $0(0 \%)$ & \\
\hline \multirow[t]{4}{*}{ Type of family } & Nuclear & $174(67.18 \%)$ & $64(24.71 \%)$ & 0.044 \\
\hline & Joint & $11(4.24 \%)$ & $10(3.86 \%)$ & \\
\hline & Hindu & $175(67.56 \%)$ & $73(28.18 \%)$ & 0.336 \\
\hline & Buddhist & $5(1.90 \%)$ & $0(0.00 \%)$ & \\
\hline \multirow[t]{2}{*}{ Religion } & Christian & $2(0.77 \%)$ & $0(0.00 \%)$ & \\
\hline & Muslim & $3(1.15 \%)$ & $1(0.38 \%)$ & \\
\hline
\end{tabular}


further categorized as overt hyperthyroidism if there was elevated level of free T3, free T4 and decreased TSH, and overt hypothyroidism, as having decrease in level of free T3 and freeT4, with high TSH. Subclinical hypothyroidism as by normal free T3, normal free T4 and elevated serum TSH level and subclinical hyperthyroid as decreased TSH and normal free T3 and free T4.

\section{Statistical analysis}

The collected data were entered in Microsoft Excel, tabulated and analyzed using SPSS (23.0 Version). Statistical analysis was done using parametric and nonparametric statistical techniques for measure of central tendency and standard deviation; correlation between thyroid status and severity of depression was analyzed using Pearson correlation. Statistical significance was assessed at $5 \%$ level of significance $(\mathrm{p}<0.05)$.

\section{RESULTS}

Among the 259 patients enrolled with a major depressive disorder in the study, 84 (32.4\%) were male, while $175(67.6 \%)$ were female. The mean age of the participants was 35.37 years. Majority of them $187(72.2 \%)$ were married and followed Hindu religion, 248 (95.8\%). Most of them, 93 $(35.90 \%)$ were illiterate. Assessment of socioeconomic status was based on the guidelines provided by Central Bureau of Statistics, government of Nepal. Majority of patients belonged to middle socioeconomic condition, $189(73.0 \%)$. The major occupation of most participants 122 $(47 \%)$ housewives and stayed in a nuclear family, $238(91.9 \%)$. Demographic data is shown in Table (1).

Of 259 participants, $74(28.57 \%)$ had a thyroid dysfunction. Sixty four patients had subclinical hypothyroidism, five had overt hypothyroidism, four $(1.5 \%)$ overt hyperthyroidism and one had subclinical hyperthyroidism (Table 3). The characteristics of the subjects who had thyroid dysfunction and normal thyroid function are shown in Table (1). Majority of patients had moderate depressive episode without somatic syndrome, 96 $(37.1 \%)$, thirty two patients $(12.4 \%)$ had moderate

\begin{tabular}{|lc|}
\hline $\begin{array}{l}\text { Table 2. Diagnosis of patients on the basis of ICD-10 } \\
\text { DCR criteria. }\end{array}$ \\
\hline $\begin{array}{l}\text { Mild depressive episode without } \\
\text { Somatic syndrome }\end{array}$ & $62(23.9 \%)$ \\
$\begin{array}{l}\text { Mild depressive episode with Somatic } \\
\text { syndrome }\end{array}$ & $15(5.8 \%)$ \\
$\begin{array}{l}\text { Moderate depressive episode without } \\
\text { Somatic syndrome } \\
\text { Moderate depressive episode with } \\
\text { Somatic syndrome } \\
\text { Severe depressive episode without } \\
\text { Psychotic symptoms } \\
\begin{array}{l}\text { Severe depressive episode with Psychotic } \\
\text { symptoms }\end{array}\end{array}$ & $96(37.1 \%)$ \\
\hline
\end{tabular}

depression with somatic syndrome and seventy seven $(29.72 \%)$ had mild and severe depression was seen in $33(20.84 \%)$ Table (2). The results demonstrated no significant association between thyroid dysfunction with the severity of depressive illness and HAMD (Table 4).

\begin{tabular}{|lc|}
\hline $\begin{array}{l}\text { Table 3. Distribution of patients on the basis of } \\
\text { thyroid status. }\end{array}$ & \\
\hline State of Thyroid & $\mathrm{N}(\%)$ \\
Euthyroidism & $185(71.4 \%)$ \\
Subclinical Hypothyroidism & $64(24.7 \%)$ \\
Subclinical Hyperthyroidism & $1(0.4 \%)$ \\
Overt Hypothyroidism & $5(1.9 \%)$ \\
Overt Hyperthyroidism & $4(1.5 \%)$ \\
\hline
\end{tabular}

Table 4. Correlation between thyroid status, type of depression and HRDS: Pearson's correlation.

\begin{tabular}{|lccc|}
\hline Variables & $\begin{array}{c}\text { Thyroid } \\
\text { status }\end{array}$ & $\begin{array}{c}\text { Type of } \\
\text { depression }\end{array}$ & $\begin{array}{c}\text { HDRS } \\
\text { levels }\end{array}$ \\
Thyroid status & 1.0 & & \\
Type of depression & 0.064 & 1.0 & \\
HRDS & 0.106 & $0.866^{*}$ & 1.0 \\
\hline
\end{tabular}

\section{DISCUSSION}

In our study the mean age of the patients was $35.37 \pm 14.47$ years. Among them almost two-third of the population were female. These findings were similar to the earlier studies where majority of patients were middle aged female. ${ }^{13,14}$

The prevalence of thyroid dysfunction in our study was $28.57 \%$. This value is higher when compared with some of the studies done in general population with a range of 1-10. ${ }^{15-17}$ However, when compared to the studies done among the patients with major depressive disorder the findings are similar. Study done by Das et al had a prevalence of $19.4 \%,{ }^{18}$ Charnsil et al showed prevalence of $22.1 \%,{ }^{19}$ and Ojha et al had $21 \%{ }^{13}$ prevalence of thyroid disorder among patients with depression.

Among those with thyroid dysfunction, $24.7 \%$ patients had subclinical hypothyroidism, $1.9 \%$ had overt hypothyroidism, $1.5 \%$ had overt hyperthyroidism and $0.4 \%$ had subclinical hyperthyroidism. This is in accordance with the study done by Ojha et al which found the prevalence of subclinical hypothyroidism being $11.4 \%$, subclinical hyperthyroidism $5.7 \%$ and overt hyperthyroidism $4.3 \%{ }^{12}$ Similar findings were found in studies which showed $1 \%$ to $4 \%$ prevalence rate of overt hypothyroidism and $4 \%$ to $40 \%$ of subclinical hypothyroidism in his patients with affective disorder. ${ }^{20,21}$

Majority of patients (49.42\%) had moderate depressive episode, while $29.72 \%$ had mild and $20.84 \%$ presented with severe depression. These findings are in concordance with the previous studies. ${ }^{12,13}$ The study showed that there is positive correlation between severity of depression and 
HAM-D scores however there was no correlation between severity of depression and thyroid disorder which is similar to the findings of Charnsil et al. ${ }^{19}$ However this is in contrast to the finding of Ojha et al which showed a positive correlation between severity of depression and thyroid dysfunction. ${ }^{12}$

In our study the mean age of the patients was $35.37 \pm 14.47$ years. Among them almost two-third of the population were female. These findings were similar to the earlier studies where majority of patients were middle aged female. ${ }^{13,14}$ The prevalence of thyroid dysfunction in our study was $28.57 \%$. This value is higher when compared with some of the studies done in general population with a range of $1-10{ }^{15-17}$ However, when compared to the studies done among the patients with major depressive disorder the findings are similar. Study done by Das et al had a prevalence of $19.4 \%$, ${ }^{18}$ Charnsil et al showed prevalence of $22.1 \%{ }^{19}$ and Ojha et al had $21 \%{ }^{13}$ prevalence of thyroid disorder among patients with depression.

Among those with thyroid dysfunction, $24.7 \%$ patients had subclinical hypothyroidism, $1.9 \%$ had overt hypothyroidism, $1.5 \%$ had overt hyperthyroidism and $0.4 \%$ had subclinical hyperthyroidism. This is in accordance with the study done by Ojha et al which found the prevalence of subclinical hypothyroidism being $11.4 \%$, subclinical hyperthyroidism $5.7 \%$ and overt hyperthyroidism $4.3 \%{ }^{12}$ Similar findings were found in studies which showed $1 \%$ to $4 \%$ prevalence rate of overt hypothyroidism and $4 \%$ to $40 \%$ of subclinical hypothyroidism in his patients with affective disorder. ${ }^{20,21}$

Majority of patients $(49.42 \%)$ had moderate depressive episode, while $29.72 \%$ had mild and $20.84 \%$ presented with severe depression. These findings are in concordance with the previous studies. ${ }^{12,13}$ The study showed that there is positive correlation between severity of depression and HAM-D scores however there was no correlation between severity of depression and thyroid disorder which is similar to the findings of Charnsil et al. ${ }^{19}$ However this is in contrast to the finding of Ojha et al which showed a positive correlation between severity of depression and thyroid dysfunction. ${ }^{12}$

\section{CONCLUSIONS}

This study concluded that there was high prevalence of thyroid dysfunction in patients with major depression. Thus screening of thyroid test among depressive patients may be helpful in proper management of cases.

\section{ACKNOWLEDGEMENTS}

The authors would like to thank all patients in the study and entire department of Psychiatry, COMSTH for their support to conduct this study.

\section{Conflict of interest: None}

\section{REFERENCES}

1. World Health Organization, DEPRESSION A Global Public Health Concern, 2012. Available at: http://www.who.int/ mental_health/ management/ depression/ whopaper depression wfmh 2012.pdf. Accessed $\overline{2} 2$ February $20 \overline{1} 6$.

2. Doris A, Ebmeier K, Shajahan P. Depressive illness. Lancet. 1999;354(9187):136975.doi:10.1016/S0140-6736(99)03121-9

PMID: 10533878

3. Rihmer Z, Angst A. Mood Disorders: Epidemiology. In: Sadock BJ, Sadock VA, editors. Comprehensive Textbook of Psychiatry. 8th ed. Baltimore: Lippincott Williams and Wilkins. 2004.

4. Dayan CM, Panicker V. Hypothyroidism and Depression. Eur Thyroid J. 2013;2 (3):16879.doi:10.1159/000353777 PMID: 24847450

5. Taylor JW. Depression in thyrotoxicosis. Am J Psychiatry. 1975; 132(5):552-53.doi:10.1176/ ajp.132.5.552 PMID: 1119620

6. Whybrow PC, Prange AJ Jr, Treadway CR. Mental changes accompanying thyroid gland dysfunction. A reappraisal using objective psychological measurement. Arch Gen Psychiatry. 1969; 20(1):48-63.doi:10.1001/ archpsyc.1969.01740130050004

PMID:4387067

7. Pilhatsch $M$, Winter $C$, Nordstrom $K$, Vennstrom B, Bauer M, Juckel G. Increased depressive behaviour in mice harboring the mutant thyroid hormone receptor alpha 1 . Behav Brain Res. 2010;214(2):18792.doi:10.1016/j.bbr.2010.05.016

PMID: 20580649

8. Hennemann G, Docter R, Friesema EC, de Jong M, Krenning EP, Visser TJ. Plasma membrane transport of thyroid hormones and its role in thyroid hormone metabolism and bioavailability. Endocr Rev. 2001;22(4): 45176. PMID: 11493579

9. Visser WE, Friesema EC, Jansen J, Visser TJ. Thyroid hormone transport in and out of cells. Trends Endocrinol Metab. 2008;19(2):5056.doi:10.1016/j.tem.2007.11.003

PMID: 18291666

10. Founoulakis KN, Lacovides A, Grammaticos P, St Kaprinis G, Bech P. Thyroid function in clinical subtypes of major depression: an exploratory study. BMC Psychiatry. 2004;4:6. doi:10.1186/1471-244X-4-6 PMID: 15113438

11. Bahls SC, de Carvalho GA. The relation between thyroid function and depression :a 
Thapa et al. Prevalence of Thyroid Dysfunction and its Relationship with Severity of..

review . Braz J Psychiatry. 2004;26(1):41-49. doi:10.1590/s1516-44462004000100012

PMID: 15057840

12. Ojha SP, Dhungana S, Chapagain $M$, Tulachan P. Association of thyroid dysfunction with depression in a teaching hospital. J Nepal Health Res Counc. 2013;11 (23):30-34. PMID: 23787522

13. Chhetry M, Sapkota N, Ojha N, Thapa S, Pandey A. Association of Thyroid Dysfunction with Mood Disorders in an OPD setting. JPAN. 2014;3(1):23-8. doi: 10.3126/ jpan.v3i1.11348

14. Bathla M, Singh M, Relan P. Prevalence of anxiety and depressive symptoms among patients with hypothyroidism. Indian $\mathbf{J}$ Endocrinol Metab. 2016; 20(4): 468-74. doi: 10.4103/2230-8210.183476 PMID: 27366712.

15. Samuels MH. Subclinical thyroid disease in the elderly. Thyroid; 8(9):803-13. doi:10.108 9/thy. 998.8.803 PMID: 9777754

16. Vanderpump MP, Tunbridge WM. The epidemiology of thyroid diseases. In Braverman LE Utiger RD, editor., eds. The
Thyroid: a Fundamental and Clinical Text. 8th ed. Philadelphia: Lippincott Williams and Wilkins;2000. 467-73p.

17. Wang C, Crapo LM. The epidemiology of thyroid disease and implications for screening. Endocrinol Metab Clin North Am. 1997;26(1):189-218. doi:10.1016/s08898529(05)70240-1 PMID: 9074859

18. Das B, Baral N, Shyangwa PM, Toora BD, Lamsal M. Altered serum levels of thyroxine, triiodothyroinine and thyroid stimulating hormone in patients with depression. Kathmandu Univ Med J (KUMJ). 2007;5 (3):330-34. PMID: 18604049

19. Charnsi C, Pilakanta S. Prevalence of Thyroid Dysfunction and Its Relationship with the severity of Major Depressive Disorder. Ann Psychiatry Ment Health. 2016;4(6): 1081.

20. Wolkowitz OM, Rothschild AJ. Psychoneuroendocrinology: The Scientific Basis of Clinical Practice. Washington: American Psychiatric Press, 2003.

21. Feldman AZ, Shrestha RT, Hennessey JV. Neuropsychiatric manifestations of thyroid

Citation: Thapa A, Karki M, Thapa A. Prevalence of Thyroid Dysfunction and its Relationship with Severity of Depression among Patients of Depression Attending Tertiary Hospital. JCMS Nepal. 2020; 16(3):128-32. 